\section{EMBRYRIDDLE}

Aeronautical University

SCHOLARLY COMMONS
Journal of Aviation/Aerospace

Education \& Research

Volume 7

Number 1 JAAER Fall 1996

Article 3

Fall 1996

\title{
Educational Course and Curriculum Needs for Corporate Aviation \\ Managers
}

Stephen M. Quilty

Follow this and additional works at: https://commons.erau.edu/jaaer

\section{Scholarly Commons Citation}

Quilty, S. M. (1996). Educational Course and Curriculum Needs for Corporate Aviation Managers. Journal of Aviation/Aerospace Education \& Research, 7(1). https://doi.org/10.15394/jaaer.1996.1185

This Article is brought to you for free and open access by the Journals at Scholarly Commons. It has been accepted for inclusion in Journal of Aviation/Aerospace Education \& Research by an authorized administrator of Scholarly Commons. For more information, please contact commons@erau.edu. 


\title{
EDUCATIONAL COURSE AND CURRICULUM NEEDS FOR CORPORATE AVIATION MANAGERS
}

\author{
Stephen M. Quilty
}

\begin{abstract}
A survey was conducted for the National Business Aircraft Association (NBAA) that identified educational content and knowledge areas thought to be important to the success of a corporate aviation flight department manager or chief pilot. The survey consisted of 49 educational course descriptions. Information about the importance of the courses was sought from NBAA member companies, specifically the flight department manager or chief pilot and the individual that the manager/chief pilot reported to in the company. The data collected were ranked and grouped to reflect those topics that were considered important to the success of a manager. Results from the study raise questions about how to best meet the educational needs identified. Aviation educational institutions and management development and training consultants are encouraged to develop and deliver courses, seminars, or curriculums that focus on developing current corporate and business aviation managers and better preparing future managers.
\end{abstract}

\section{INTRODUCTION}

The NBAA was organized in 1946 to represent the aviation interests of companies that are involved in business aviation or own and operate aircraft as a means to conduct their business. One of the primary purposes of the NBAA is "to foster among its members the highest degree of operating efficiency and safety" (NBAA, 1995). Education and training of NBAA members are key components for meeting that objective and are central responsibilities of the Corporate Aviation Management Committee.

Through the committee, a task force was formed of members from the NBAA and the University Aviation Association (UAA) to study and formulate a recommended educational knowledge base to help develop current aviation department managers and better prepare future ones. The study required surveying NBAA members to obtain data as to the knowledge and skills deemed important to the success of a flight department manager. This paper presents the survey results along with an explanation of the study limitations. Though the data can be integrated into the educational mainstream as presented, philosophical questions are raised as how best to address the needs of the industry.

NBAA representation reflects the use of an aircraft in corporate and business operations to further the goals of a company. This has implications that affect the economic viability of the company. The aviation department can be deemed an asset or a liability to a company depending on its contribution to the bottom line. Effective management of the asset known as the aviation department is as important to the success of the company as any other asset or department in the organization.

In 1986 the NBAA developed a management guide to provide assistance to those individuals responsible for managing the corporate and business aviation function. The guide was developed as a result of increasing requests by members for basic information on managing the complexities of an aviation department in an organization. The need for additional knowledge and guidance about management topics stemmed from several different factors.

One factor was that many individuals charged with managing an aviation department had originally received education and training in piloting and operating an aircraft. They were not necessarily as well-versed in managing people or a high-value business operation. A second factor was the increasing integration of the aviation department into the organization. This required greater asset management with bottom-line contributions, greater interaction with other organizational departments, 
Table 1

Sample Survey Question

Mark to what degree you believe the aviation department manager-chief pilot should understand and be able to demonstrate competency in each of the specific topic items:

High Average Not

degree degree req'd

Managerial Accounting and Budgeting $\begin{array}{lllll}5 & 4 & 3 & 2 & 1\end{array}$

Be able to develop and administer an operating and capital budget. Be able to monitor and make decisions regarding cash flow. Be able to use budget information to make operational decisions. Be able to plan and project future equipment and facility needs.

greater safety and efficiency in operation, greater public sensitivities, and greater involvement with governmentregulations. A third factor influencing the request for information was the increasing technological complexities of aircraft operations and the increased skill and knowledge requirements in aviation departments to conduct those operations.

In the last decade, NBAA members have expressed increased concern about the continued viability (and survivability) of business aircraft operations because of the perceived inadequacies in management education and skill preparation of individuals (NBAA, 1994). It was evidenced in some cases that individuals without an aviation background were assigned to manage the aviation department at major corporations. It was also evidenced that some aviation departments at smaller companies were dissolved because the aircraft's business value was not managed properly or carefully enough to satisfy upper management.

\section{PURPOSE OF THE STUDY}

A study was previously undertaken in 1993 by a joint task force of the NBAA and the UAA to investigate the feasibility of a comprehensive management development program (NBAA, 1994). It was highlighted in that study that $75 \%$ of the 673 responding NBAA members agreed that corporate aviation needed a means to improve the way individuals were prepared to manage aviation department functions.
Based on the results from the 1993 study, the task force determined it was necessary to further identify those knowledge and skill areas that were deemed important to the success of a person in the position of a flight department manager or chief pilot. Hence, the purpose of this study was to identify those knowledge and skill areas. The study was targeted to the flight department manager/chief pilot (FDM/CP) and the company officer (CO) to whom the FDM/CP reported. From this data, a recommended list or curriculum of educational knowledge and skill areas could be developed.

The UAA was invited to participate in the task force because of its members' expertise in the development of aviation curriculum material. UAA member schools also would most likely have the means and ability to deliver the programs that might result from the study. Up to the time of the 1993 study, few universities had specialized corporate aviation courses or had programs focusing solely on business and corporate aviation. The reason for so few offerings is the focus for continued discussion and debate about balancing the needs of the industry with the constraints of the academic environment. This paper attempts to frame that discussion and debate in addition to presenting the results of the study.

\section{SURVEY CONTENTS AND METHODOLOGY}

A survey was developed to identify important knowledge and skill requirements necessary to the success 
Table 2

Survey Response Demographics

\begin{tabular}{lll}
\hline & FDM/CP & $\frac{\mathrm{CO}}{2628}$ \\
Distributed & 2628 & \\
Received & 384 & 169 \\
\% Response & 14.6 & 6.4 \\
& & \\
\hline
\end{tabular}

Note: $F D M / C P=F l i g h t$ Department Manager/Chief Pilot; $\mathrm{CO}=$ Company Officer

of an aviation flight department manager or chief pilot. The knowledge section of the survey was developed using various UAA college catalogs to identify existing courses that may be important or used in the operation of a flight department. A short summary or example of each course content area was provided to assist respondents in understanding the topic (Table 1). Information also was requested on each survey for the name, title, company, number of aircraft operated, and number of employees in the flight department.

The survey sent to the FDM/CP distinguished itself from the survey sent to the $\mathrm{CO}$ by the addition of a 10-item aviation topic section. This section was not included on the $\mathrm{CO}$ survey as it was reasoned a $\mathrm{CO}$ would not necessarily have the requisite detailed knowledge to respond to all the specific aviation course items. It was further reasoned that the FDM/CP responses would be the best indicator for identifying the importance of the aviation topics due to their experience in those areas.

The survey contained a list of 49 course descriptions along with a rating scale for each. Appendixes $A$ and $B$ provide a complete listing of those course items listed in the survey. The intent for listing the numerous topic items was to provide the widest selection from which to choose the important knowledge base requirements. Fine art and natural science courses were not listed because the focus was more on general business or management topics.

A linear scale of $5,4,3,2,1,0$ was used, with 5 indicating a high degree of knowledge requirement, 3 an average degree of knowledge requirement, and 0 indicating no knowledge requirement. This rating system allows for a range of assessment on the importance of an item.

Two surveys each were mailed to all NBAA voting members $(\mathrm{N}=2628)$. One survey was to be completed by the FDM/CP. The second survey was to be completed by the $\mathrm{CO}$ to whom the flight department manager/chief pilot reported.

The surveys were distributed by mail to the voting members in September and October of 1995. The cover letter requested that the FDM/CP forward the CO survey directly to their reporting officer. Separate return mail envelopes were provided for each. The survey response rates are shown in Table 2. Data analysis was performed by the Statistical Consulting Center at Bowling Green State University.

\section{RESULTS}

In the survey, specific course content items were grouped into common sections. With the exception of the aviation topic area previously noted as being included on only the FDM/CP survey, evaluation and comparison were made of the ranking of the mean values between the FDM/CP and the CO responses to the topics. Table 3 provides a summary of the analysis and shows the number of topic items in each topic area and the average of the means for each topic area.

In assessing the significant difference among the topic means, a repeated measures analysis of variance was performed. The analysis looked at one mean and compared it to others to see what differences existed between the means. A Tukey analysis was then conducted to identify where those differences occurred. The Tukey analysis allows for clustering or grouping together of topics having similar weight and value.

Appendixes A and B show the groups resulting from the Tukey analysis. The groups or clusters in the Appendixes identify those items in the group that are statistically tied to only the first item in the group. The number of items in each group vary due to the point at which the mean variance becomes significant. Appendix A has eight groupings compared to five groupings in Appendix B due to two factors: (a) the aviation topic 
Table 3

Summary of the Average of the Means for Topic Areas

\begin{tabular}{llll}
\hline & & $\begin{array}{l}\text { FDM/CP } \\
\text { Average of } \\
\text { Means } \\
(\underline{N}=384)\end{array}$ & $\begin{array}{l}\text { CO } \\
\text { Average of } \\
\text { Means } \\
(\underline{N}=169)\end{array}$ \\
& Topic Items & \\
& & & \\
Aviation & 10 & 4.41 & - \\
Communication & 6 & 4.37 & 4.09 \\
Marketing & 2 & 4.10 & 3.66 \\
Business Administration & 5 & 3.96 & 3.69 \\
Psychology \& Sociology & 5 & 3.74 & 3.55 \\
Management & 7 & 3.72 & 3.44 \\
Legal & 5 & 3.67 & 3.45 \\
Accounting \& Finance & 7 & 3.48 & 3.14 \\
Environmental & 3 & 3.33 & 3.58 \\
Economics & 4 & 2.86 & 2.52 \\
Computer, M.I.S. \& Technology & 3 & 2.82 & 2.59 \\
Mathematics & 2 & 2.00 & 2.01 \\
& & & \\
\hline
\end{tabular}

Note: $\mathrm{FDM} / \mathrm{CP}=$ Flight Department Manager/Chief Pilot; $\mathrm{CO}=$ Company Officer of each group for the $\mathrm{CO}$ rankings.

By removing the aviation topics from the FDM/CP rankings, better comparison can be made between the FDM/CP and $\mathrm{CO}$ rankings. Though in reverse order, the first three topic items for both rankings were business and professional ethics, interpersonal communication, and aviation and governmental regulation. The next three topic items were also the same but not in the same order. They were personnel management, basic business principles, and management principles. And except for the CO's rating of occupational safety, the next three topic items were the same but not in the same order. They were organizational communication, small group communication, and conflict management.

Outside of the aviation topic

items were included in the survey to FDM/CP but not to the CO; and (b) the number of responses for each affect the variances.

The groups were identified by determining at what point a significant difference exists between the first topic item of each group. For example, in Appendix A all topics in Group 1 are related to aviation regulatory compliance. In Group 2, all topics are related to basic business operations. Basic business operations is the first topic item that is significantly different from aviation regulatory compliance. There are, however, other topics in Group 1 that are not significantly different than items in Group 2, such as management principles versus small group communication.

Table 4 identifies which groups have significant differences between the first topic item of each group for the FDM/CP rankings. Table 5 identifies which groups have significant differences between the first topic item area, only the communication topics had a combined mean greater than 4.00 on both rankings (combined mean average $=4.23$ ). For the aviation-specific topics, only one aviation course was not ranked by FDM/CP's in the first two groups. That course was the history of air transportation and it was the only aviation topic to have a mean less than 4.16 (mean $=3.01$ ).

Agreement existed between the two different categories of respondents on those educational items occupying the bottom of the rankings. Topic items deemed not as important for the success of the flight department manager were (not in order) labor economics, micro economics, taxation, algebra and trigonometry, calculus, and computer-aided design (means less than 2.69).

\section{STUDY LIMITATIONS}

Concern was expressed by the task force for the low overall response rate. It was deemed low because the 
Table 4

FDM/CP Matrix Showing Significant Differences Between Groups (from Appendix A)

$\begin{array}{llllllll}\text { Group } 1 & \text { Group } 2 & \text { Group } 3 & \text { Group } 4 & \text { Group } 5 & \text { Group } 6 & \text { Group } 7 & \text { Group } 8\end{array}$

\begin{tabular}{|c|c|c|c|c|c|}
\hline Group 1 & $\mathrm{X}$ & $\mathbf{X}$ & $\mathbf{X}$ & $\mathrm{X}$ & $\mathrm{X}$ \\
\hline Group 2 & & $\mathbf{X}$ & $\mathbf{X}$ & $\mathrm{X}$ & $\mathrm{X}$ \\
\hline Group 3 & & & $\mathbf{X}$ & $\mathrm{X}$ & $\mathrm{X}$ \\
\hline Group 4 & & & & $\mathrm{X}$ & $\mathrm{X}$ \\
\hline Group 5 & & & & & $\mathrm{X}$ \\
\hline Group 6 & & & & & \\
\hline Group 7 & & & & & \\
\hline Group 8 & & & & & \\
\hline
\end{tabular}

Note: Tukey critical value $w=q .05(49,8064) \approx 6.17$.

$\mathrm{X}=$ significant difference exists between the first topic items of the compared groups.

NBAA usually experienced rate of returns from $30 \%$ to $75 \%$ for many of its other surveys. It is suggested that the lower rate could well be due to the perceived length of the survey (average trial completion time was 13 minutes) and the short response time request of three weeks. Also, dissemination of the survey to the company officers was dependent on the FDM/CP forwarding it to them. It is unknown how many surveys were forwarded to company officers. If it assumed that those FDM/CP's who responded to the survey also forwarded the surveys to their CO's for completion, then the CO returns reflect a 43.5\% return of those CO's receiving the survey. For purposes of the task force study, a $14.6 \%$ and $6.4 \%$ return for the FDM/CP and CO surveys, respectively, was still considered useful because no other similar information existed.

Whereas the survey was cross-sectional in scope, errors may exist in applying the findings to specific operations. It is well understood in the aviation field that differences exist in the duties and responsibilities of flight department managers or chief pilots depending on the organizational structure, size of the company, and type of operation. This would affect how one responded to a particular topic. An example would be the rating of environmental law as very important by a FDM/CP at one particular company because he or she is responsible for handling environmental issues associated with aviation fuel tanks, deicing, or noise. Another FDM/CP may rate environmental law low because their organization is of such size as to have a separate person or staff function responsible for handling those issues.

Another example would be international business. The rankings could well be affected by whether the company conducts international operations. If it does, then a high rating would be expected. A low rating would be expected from an individual whose company operates exclusively within national boundaries. The survey did not ask whether environmental disputes were occurring or whether international operations took place.

One other limitation placed on the study relates to the educational knowledge of the respondents. Not knowing their educational background could have an effect on the results, in that disciplines or skills learned or practiced are more likely to be implemented or used. For example, an individual having an educational background in or an understanding of business economics 
Table 5

CO Matrix Showing Significant Differences

Between Groups (from Appendix B)

Group 1 Group 2 Group 3 Group 4 Group 5

$\begin{array}{llll}\text { Group 1 } & \mathbf{X} & \mathbf{X} & \mathbf{X} \\ \text { Group 2 } & & \mathbf{X} & \mathbf{X} \\ \text { Group 3 } & & & \mathbf{X} \\ \text { Group 4 } & & & \end{array}$

Group 5

Note: Tukey critical value $w=q .05(49,8064) \approx 6.17$.

$\mathrm{X}=$ significant difference exists between the first topic items of the compared groups.

is more likely to incorporate or recognize its use in operation and therefore would consider it more important than someone who did not have similar knowledge or education.

\section{DISCUSSION}

In a speech given at the fifth annual General Aviation Forecast Conference, UAA President James E. Crehan called on the aviation industry to define future personnel needs in terms of entry-level qualifications and experiences so that UAA member institutions could respond to those needs (Crehan, 1995). The position of flight department manager or chief pilot is not an entrylevel position. However, the path to such a position is rooted in a foundation for understanding and applying basic knowledge and skills. This paper helps to articulate future personnel knowledge requirements for business and corporate aviation and outlines curriculum items for meeting those needs.

Based on the results from the survey, it is relatively easy to identify what FDM/CP's and CO's believe are the most important knowledge areas for aviation department managers. Despite a low return rate, reliance on the $\mathrm{CO}$ responses may be more prudent than the FDM/CP responses, the argument being that the $\mathrm{CO}$ is the best person to evaluate the knowledge and skill requirements for the $\mathrm{FDM} / \mathrm{CP}$ position, rather than the person in that position. It is not known what the educational background of the respondents were. This could have an effect on the results, in that disciplines or skills not learned or practiced will not be implemented or used. The FDM/CP responses are best used for identifying what knowledge is being used. The $\mathrm{CO}$ responses are best used for identifying what knowledge is needed.

For those who provide training seminars and workshops to the industry, the first two groups shown in Appendix A and B should receive the most attention. Developing a university curriculum focusing on corporate and business aviation, however, may be a little more difficult to address. The NBAA/UAA task force chose to not recommend or endorse a specific curriculum outline. Instead it chose to consolidate the knowledge items into four general themes and then articulate outcomes for those themes. The themes identified were leadership, communication, management, and business administration. The expected outcomes would then spell out performance requirements that would be obtainable through acquisition of the knowledge topics.

The data show that several of the courses normally associated with university curriculums in management were rated very low. For instance, calculus, algebra, micro and macro economics, business statistics, and management science all ranked in the last two groups for both FDM/CP's and CO's. Yet a basic management curriculum accredited by the American Assembly of Collegiate Schools of Business calls for a knowledge foundation in those courses (AACSB, 1993). It is difficult to imagine that in practice a FDM/CP does not use the basic theories and concepts in those courses.

The reason for the low rankings of the basic courses is not clear. They could have been ranked low simply because they are considered fundamental compared to the other topics. Respondents may have had the expectation that an individual would have certain basic knowledge to have made it to the level of consideration 
for a flight department manager. A second reason could be that theory and concepts taught in those courses are not well-discerned in practice. However, there were specific comments from flight department managers as to the value of economics, statistics, and calculus. The comments seem to have centered on the degree to which the knowledge should be obtained, understood, and practiced. This has implications for developing a university aviation curriculum in that basic knowledge concepts of economics, statistics, and other similar courses need to be incorporated into courses such as aviation safety, transportation analysis, and aircraft selection and outfitting.

Further implications focus on the constraints of university accrediting agencies and university policies that require certain basic courses, and on the constraint for the number of credit hours required for graduation. For instance, the AACSB (1993) requires each undergraduate curriculum to have at least a $50 \%$ general education component. That percentage of general education exposure would conflict with the ground and flight course requirements needed to obtain the ratings and proficiencies necessary to qualify as a pilot. This raises the question then of what is the proper balance of courses that will result in a reasonable number of credit hours, meet university accreditation and policy requirements, and satisfy the needs of the industry?

Answering that question requires further dialogue and debate among academicians and the industry. The Council on Aviation Accreditation (CAA) states in its criteria for aviation management:

Care must be taken to avoid preparation in a field that is too narrow; however, without adequate depth of study in a specific area, the student is not likely to have the special expertise that will set him or her apart from others. (CAA, 1992, p. 27)

The content suggested for the flight education curriculum does not require any management-focused courses. A review of several UAA member institutions having corporate aviation programs shows few of the courses identified high in the rankings as being part of their curriculum. Many of the university programs focus on the flight aspects. Petrin and Young (1994) provided their perception of what should be included in a professional pilot curriculum. Their basic groupings, however, contain a similar number of specific topic items as those listed in this survey. They do not address how to resolve the issue of fitting so many courses into the curriculum.

Further dialogue and debate should be centered on the mission and role of an aviation program at the two-year or four-year undergraduate level, and on how to balance the needs of university accreditation requirements and the need for specialized training and education in aviation. Should the role be that of preparing an individual with the specific skills needed or a broad educational perspective? It is a debate pitting specialized training against general education.

If the role of an undergraduate program is to provide a basis for learning future skills (hence arguing the side for a broad educational background), then how do we in the academic community meet the needs of the industry for specific capabilities? And if we focus on providing the specific skills to meet the needs of the industry (hence taking the side for skill training), how do we justify our programs to the academic demands of the general university or accreditation bodies?

One alternative may be to assess the level at which curriculum topics are introduced. Truitt, Hamman, and Palinkas (1994) discussed the appropriateness of a graduate program in aviation administration as meeting the demands and challenges associated with airport management. Perhaps the same consideration for a graduate program should be given to other specialized aspects of aviation management, in particular corporate aviation management. Or perhaps the preparatory ground and flight courses should be focused at the two-year colleges, with the four-year universities focusing on the more advanced ratings and educational requirements. Another alternative is to maintain the current curriculums but focus on providing the aftermarket courses, seminars, workshops, or other focused training that the industry demands.

In any case, the NBAA has taken the steps to identify for the aviation education and training community what its members feel are the necessary knowledge 
requirements for the success of an aviation flight department manager. It is now up to the aviation education community to respond to those needs.

\section{SUMMARY}

The mission of the joint NBAA/UAA task force was to improve the management of corporate aviation flight departments by (a) defining the knowledge and ability requirements of the successful flight department manager; and (b) proposing a management development curriculum that imparts this knowledge and allows participants to acquire and demonstrate these abilities. The survey results were used to assist the task force in fulfilling its mission.

Results from the study point to general and specific educational topics that flight department managers or chief pilots feel constitute an important part of the manager's knowledge base. It also identifies what company officers (the person the flight department manager reports to) believe are important educational knowledge requirements for the manager. Information derived from the survey can be used by aviation educational institutions and management development and training consultants to construct courses, workshops, or curriculums that focus on better preparing future corporate and business aviation managers.

Debate remains on how best to construct a corporate aviation management curriculum that meets the requirements of the educational structure and the needs of the industry. The NBAA/UAA task force identified the areas of leadership, communication, management, and business administration as primary bodies of knowledge. The task force felt the establishment of specific curriculum outlines for universities are better addressed in the UAA, the individual universities and colleges, and the CAA. The aviation education community should discuss and debate these issues for the betterment of future aviation students and the aviation industry. 


\section{Appendix A}

Flight Department Manager/Chief Pilot (FDM/CP) Statistical Grouping of Topic Items (N=384)

\section{Mean Group 1}

4.78 Aviation Regulatory Compliance

4.78 Flight Operation

4.74 Operating Procedures

4.67 Aviation Safety \& Program Management

4.66 Aviation \& Governmental Regulation

4.64 Interpersonal Communication

4.60 Business \& Professional Ethics

4.58 Vendor Selection

4.56 Management Principles

4.55 Aircraft Selection, Purchase \& Outfitting

4.55 Personnel Management

\section{Mean Group 3}

4.16 Airport \& Fixed Base Operation

4.14 Business Policy \& Strategy

4.00 Logic, Reason \& Decision

4.00 Occupational Safety

3.92 Presentational Speaking

3.90 Marketing
Mean Group 2

$4.51 \quad$ Basic Business Operations

4.44 Scheduling \& Dispatch

4.45 Small Group Communication

4.42 Conflict Management

4.42 Organizational Communication

4.39 Maintenance Management

4.38 Written Communication

4.32 Managerial Acct'g \& Budgeting

4.30 Transportation Analysis

\section{Mean Group 5}

3.63 Industrial \& Organizational Psych.

3.59 Hazardous Material Management

3.55 Liability Law

3.50 Financial Accounting

3.49 Employment Law

3.46 Work Assessment

3.38 Business Law

Mean Group 7

2.99 Environmental Studies

2.99 Op Systems, Electronics \& Network

2.98 Management Science

2.81 Real Estate, Facility \& Asset Mgmt.

2.75 Business Statistics

2.73 - Macro Economics
Mean Group 4

3.88 Cost Accounting

3.83 Social Psychology

3.78 General Psychology

3.78 International Business

3.77 Organ'l Theory, Behavior, Develop.

3.71 Purchasing \& Materials Management

3.69 Risk Management

3.68 Organizational Politics

3.66 Word Proc., DB, Spreadsht, Graphics

\section{Mean Group 6}

3.34 Accounting Information Systems

3.33 Business Economics

3.27 Environmental Law

3.21 Auditing

3.01 History of Air Transportation

Mean Group 8

2.69 Labor Economics

2.67 Micro Economics

2.39 Taxation

2.19 Algebra, Trigonometry \& Geometry

1.84 Calculus

1.80 CAD \& Illustration 


\section{Appendix B \\ Company Officer (CO) Statistical Grouping of Topic Items ( $N=169)$}

\section{Mean Group 1}

4.60 Business \& Professional Ethics

4.45 Interpersonal Communication

4.44 Aviation \& Gov'l Regulation

4.36 Personnel Management

4.34 Basic Business Operations

4.34 Management Principles

4.22 Occupational Safety

4.20 Organizational Communication

4.17 Small Group Communication

\section{Mean Group 3}

3.60 Hazardous Material Management

3.53 Presentational Speaking

3.52 Social Psychology

3.49 Purchasing \& Materials Management

3.47 General Psychology

3.47 Marketing

3.46 Risk Management

3.46 Organizational Politics

3.44 Cost Accounting

3.39 Organ'l Theory, Behavior \& Develop.

3.38 Word Process, DB, Spreadsht \& Graph

3.38 Industrial \& Organizational Psych.

3.36 Liability Law

3.29 Work Assessment

3.21 International Business

3.20 Financial Accounting

3.18 Employment Law

3.16 Business Economics

\section{Mean Group 2}

4.14 Conflict Management

4.08 Logic, Reason \& Decision

4.02 Written Communication

3.98 Managerial Accounting \& Budgeting

3.85 Business Policy \& Strategy

3.85 Transportation Analysis

Mean Group 4

3.14 Environmental Law

3.11 Business Law

2.98 Accounting Information Systems

2.93 Environmental Studies

2.83 Auditing

2.78 Op. Sys, Electronics \& Networks

Mean Group 5

2.62 Management Science

2.46 Business Statistics

2.44 Real Estate, Facility \& Asset Mgmt.

2.41 Labor Economics

2.28 Macro Economics

2.23 Micro Economics

2.14 Algebra, Trigonometry \& Geometry

2.08 Taxation

1.88 Calculus

1.62 CAD \& Illustration 
Stephen M. Quilty holds an M.A. in Communication and a B.S. in Aviation Management and Technology; both degrees are from Western Michigan University. He is an assistant professor of aerotechnology in the Department of Technology Systems, College of Technology, at Bowling Green State University, Ohio.

\section{REFERENCES}

American Assembly of Collegiate Schools of Business. (1993, April). Achieving quality and continuous improvement through self evaluation and peer review: Standards for business accreditation. St. Louis, MO: Author.

Crehan, J. A. (1995). Educational opportunities in aviation education. The Journal of Aviation/Aerospace Education and Research, 5(2), 7-10.

Council on Aviation Accreditation. (1992, August). Accreditation standards manual. Opelika, AL: Author.

National Business Aircraft Association. (1994, April). Management certification for the corporate flight department: $A$ feasibility study. Washington, DC: Joint Task Force of the University Aviation Association and the National Business Aircraft Association.

National Business Aircraft Association. (1995). NBAA mission statement. NBAA directory of member companies, aircraft and personnel. Washington, DC: Author.

Petrin, D. A., and Young, J. P. (1994). Professional pilot studies: Proposed content. The Journal of Aviation/Aerospace Education and Research, 4(3), 31-36.

Truitt, L. J., Hamman, J. A., and Palinkas, K. G. (1994). Graduate education in airport administration: Preparing airport managers for the 21st century. The Journal of Aviation/Aerospace Education and Research, 4(2), 9-16. 